\title{
Examination of Expandable Stent that Simulates Shape of Namako-Folding by FEM
}

$\begin{array}{ccclllll}\text { 学 } & \text { ○森脇 } & \text { 貫氏 } & \text { （兵庫県立大大学院） } & \text { 正 } & \text { 海津 } & \text { 浩一 } & \text { (兵庫県立大) } \\ \text { 正 } & \text { 日下 } & \text { 正広 } & \text { (兵庫県立大) } & \text { 正 } & \text { 木村 } & \text { 真晃 } & \text { (兵庫県立大) }\end{array}$

Kanji MORIWAKI, Koichi KAIZU, Masahiro KUSAKA, Masaaki KIMURA University of Hyogo, 2167 Shosha Himeji, Hyogo, Japan

1. 緒 言

ステントとは，血管の狭窄に対して血管の内側から支持 して血管を広げた状態で保持するために血管内部に留置す る筒状の網のことである．ステントはカテーテルの先端に つけられて血管内を通って患部に運ばれるので，できるだ け小さいことが望ましく, 狭窄部では再び狭窄しないよう に血管壁を支える半径剛性が必要であり，かつ人体の動き に対応するために柔軟な構造であることが望ましい，本研 究では, FEM 解析汎用ソフト LS-DYNA を用いて, 折紙の 折り方の 1 つであるなまこ折りを模擬したステントモデル の内側から円周方向に力を作用させるシミュレーションを 行うことにより，血管内に留置されるステントの拡張の様 子についての検討を行った。

\section{2. 解析モデル}

Fig.1 に解析に用いたステントのモデルを示す. Fig.1(a)に 解析モデルの全体図を，Fig.1(b)に解析モデルを構成する基 本となるセル形状を示している. 解析モデルは半径 $0.5 \mathrm{~mm}$, 長手方向 $1.554 \mathrm{~mm}$ ，厚さ $0.01 \mathrm{~mm}$ の円柱状になるように基 本セルが組み合わされている. セル形状は高さ $0.177 \mathrm{~mm}$, 円周方向の長さ $0.1912 \mathrm{~mm}$ となっている. セル形状の縦方 向のストラッド太さは $0.0109 \mathrm{~mm}$, セル中央部の横方向の ストラッドの太さは $0.0079 \mathrm{~mm}$, 長さは $0.0436 \mathrm{~mm}$ となって おり，斜めの太さは $0.0134 \mathrm{~mm}$ となっている. また，解析 モデルは対称性を考慮して $1 / 4$ の大きさで作成した。 なお, このモデルの体積は $0.0041 \mathrm{~mm}^{3}$ となっている.

\section{3. 解析条件}

材料モデルは多直線近似等方弾塑性体構成式を用い，材 料は, 質量密度 $7900\left[\mathrm{~kg} / \mathrm{m}^{3}\right]$, ヤング率 $208[\mathrm{GPa}]$, ポアソ
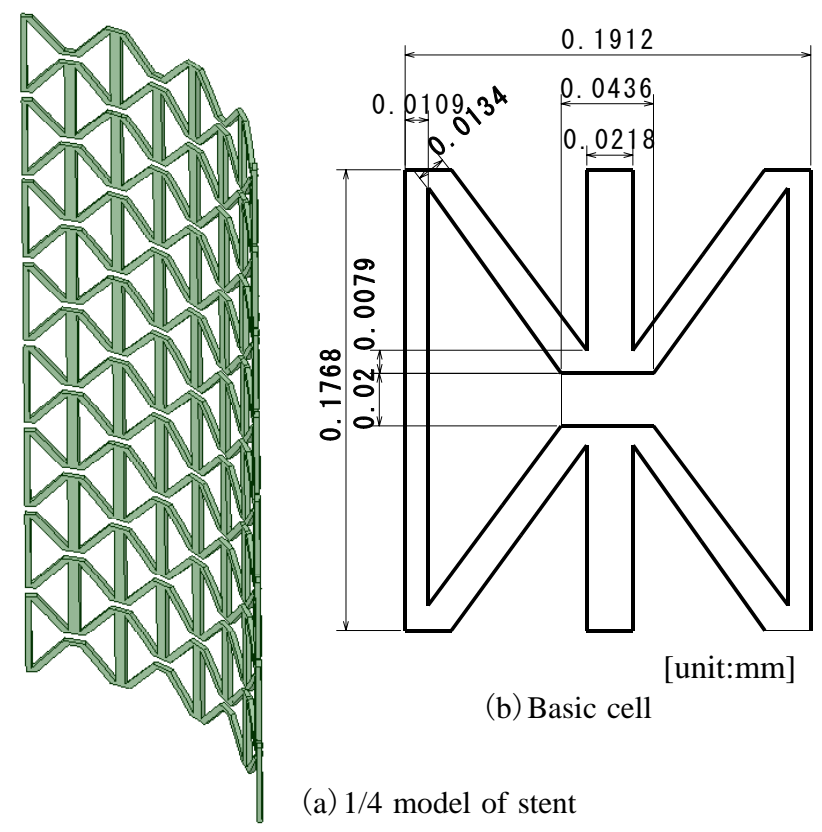

(b) Basic cell

(a) $1 / 4$ model of stent

Fig.1 Analysis model.
ン比 0.3, 降伏応力 246[MPa]の SUS316L を仮定した. ス テントを展開させるには, 先端が風船状になったバルーン カテーテルでステントの内側から内圧を加えることを想定 し, バルーンカテーテルの標準拡張圧である 6atm と最大拡 張圧である $14 \mathrm{~atm}$ の条件で内側から外側に向けて力を作用 させた後に除荷する解析を行った. モデルは $1 / 4$ で作成を 行っているので，モデルの対称境界面は垂直な方向に拘束 し，平行な方向には移動できるようにした.

\section{4. 解析結果}

解析結果の例として, Fig.2 に最大拡張圧を負荷させた時 の解析前のモデルと解析後のモデルを比較した様子を示寸. Fig.2(a)，（b) はそれぞれモデルを横から見た図と上から見 た図を示している，標準拡張圧を負荷させた後の半径方向 は拡張前と比べて約 16\%, 長手方向に約 27\%拡張される結 果となった. 最大拡張圧を負荷させた後の半径方向は拡張 前と比べて約 29\%, 長手方向に約 48\%拡張される結果とな った.このような結果が得られたのは解析モデルの斜めに なっている部分が力を作用させたことで半径方向に広がり, 半径方向の広がりに対応して長手方向にも伸びることが原 因であると考えられる。このことからなまこ折り形状を用 いることで半径方向だけでなく, 長手方向にも拡張できる ことが分かった.

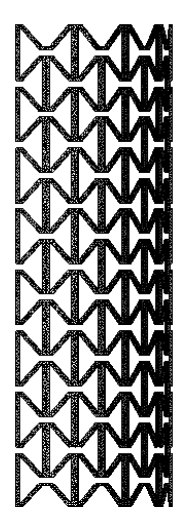

(a) Side view
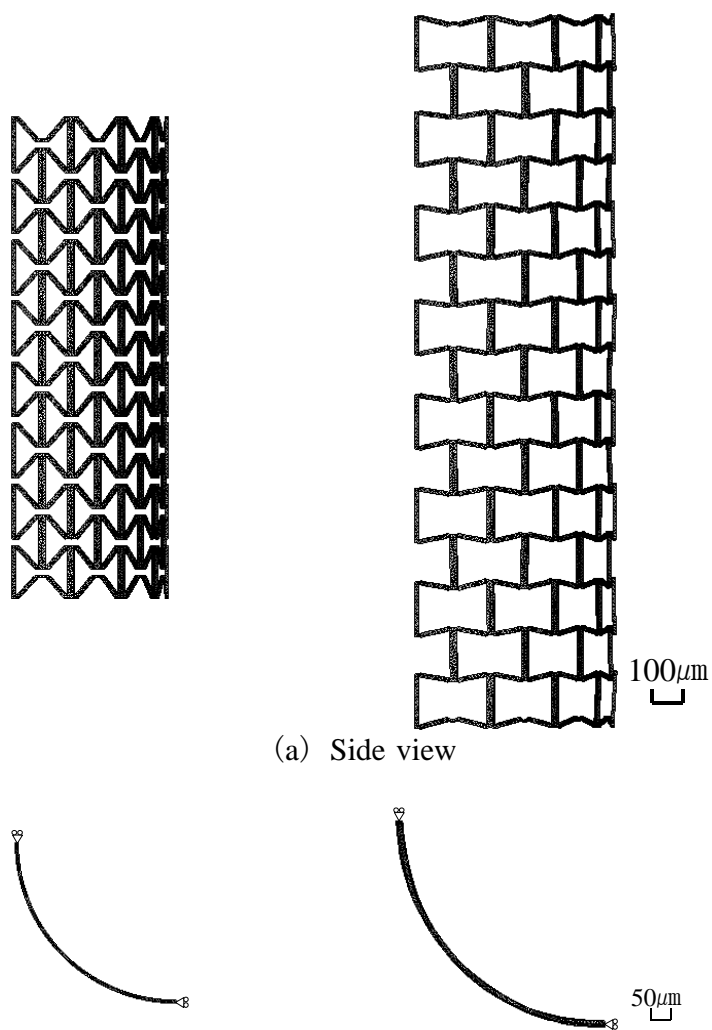

$50 \mu \mathrm{m}$

(b) Top view

Fig.2 Analysis result of proposed stent (1.4MPa). 